Supplementary Electronic Information for:

\title{
$\mathrm{CO}_{2}$ EMISSIONS REDUCTION BY INTEGRATING CONCENTRATING SOLAR POWER INTO LITHIUM MINING
}

\author{
Pablo Dellicompagnia, Judith Franco ${ }^{a}$, Victoria Flexer ${ }^{b, *}$ \\ anstituto de Investigaciones en Energía No Convencional (INENCO), 5150 Bolivia Av. (4400). Salta, \\ Argentina. \\ ${ }^{\mathrm{b}}$ Centro de Investigación y Desarrollo en Materiales Avanzados y Almacenamiento de Energía de Jujuy \\ (CIDMEJu), Juan A. Rojas esq. San Martín (4612). Palpalá, Jujuy. Argentina.
}

*Corresponding author: Prof. Victoria Flexer (vflexer@unju.edu.ar) 
Table S1

Existing facilities (actively producing at industrial level) for lithium mining for concentrated brines, location, operating company and source of information for their energy consumption. Information available at time of writing (August 2021)

\begin{tabular}{|c|c|c|c|}
\hline Country & $\begin{array}{l}\text { Deposit } \\
\text { Name } \\
\text { (salt lake) }\end{array}$ & Operator Name $\S$ & Source of information on energy sources / comments \\
\hline Argentina & Olaroz & $\begin{array}{l}\text { Sales de } \\
\text { Jujuy/Orocobre }\end{array}$ & $\begin{array}{l}\text { As stated by the company in their sustainability report: } \\
\text { https://www.orocobre.com/wp/?mdocs-file }=5506\end{array}$ \\
\hline Argentina & $\begin{array}{l}\text { Hombre } \\
\text { Muerto }\end{array}$ & $\begin{array}{l}\text { FMC } \\
\text { Lithium/LIVENT/ } \\
\text { Minera del } \\
\text { Altiplano }\end{array}$ & https://livent.com/es/sustainability/ \\
\hline Argentina & Cauchari & $\begin{array}{l}\text { EXAR/Gangfeng } \\
\text { Lithium }\end{array}$ & $\begin{array}{l}\text { https://www.mineraexar.com.ar/ } \\
\text { https://www1.hkexnews.hk/listedco/listconews/sehk/2021/0428/2021 } \\
\underline{\text { 042802144.pdf }}\end{array}$ \\
\hline Chile & Atacama & $\begin{array}{l}\text { Sociedad Quimica } \\
\text { y Minera de Chile } \\
\text { (SQM) }\end{array}$ & $\begin{array}{l}\text { *Supporting information of Stamp et al. }{ }^{1} \text { lists a large consumption } \\
\text { of fossil fuels } \\
\text { *As stated by the company https://www.sqm.com/en/medio- } \\
\text { ambiente/\#energy tab. See below }\end{array}$ \\
\hline Chile & Atacama & Albemarle & $\begin{array}{l}\text { "About } 2 \% \text { of the energy mix (excluding passive solar ponds) is } \\
\text { renewable (photovoltaic) and } 11 \% \text { of the energy consumption is } \\
\text { covered under emission-limiting regulations." (which does not mean } \\
\text { renewables) } \\
\text { https://www.albemarle.com/sustainability/sustainability-reports- }\end{array}$ \\
\hline USA & $\begin{array}{l}\text { Clayton } \\
\text { Valley } \\
\text { (Silver } \\
\text { Peak) }\end{array}$ & $\begin{array}{l}\text { Rockwood } \\
\text { Holdings, Inc. }\end{array}$ & $\begin{array}{l}\text { https://www.yumpu.com/en/document/read/31872978/rockwood- } \\
\text { sustainability-report-rockwood-holdings-inc }\end{array}$ \\
\hline China & Chaerhan & $\begin{array}{l}\text { Qinghai Lanke } \\
\text { Lithium Industry }\end{array}$ & No information could be found. \\
\hline China & $\begin{array}{l}\text { West } \\
\text { Taijinar }\end{array}$ & $\begin{array}{l}\text { CITIC Guoan } \\
\text { Lithium Science } \\
\& \text { Technology }\end{array}$ & No information could be found. \\
\hline China & Zhabuye & $\begin{array}{l}\text { Tibet Mineral } \\
\text { Development }\end{array}$ & No information could be found. \\
\hline
\end{tabular}

All web links are active at time of writing.

$\S$ Often different operator names are found for the same active facility. This is normally the case when an international company operates under a local name. Alternatively, some operations correspond to a joint venture of several companies. Facilities listed following US Geological Service Lithium Statistics and Information latest report. Last update published in September 2020. Accessed $7^{\text {th }}$ August 2021 via: https://www.usgs.gov/centers/nmic/lithiumstatistics-and-information

Similar information also available in Flexer et $a .^{2}$

\section{ISpecial comment on SQM}

As of August 2021, the company claims: "SQM uses a high percentage of solar energy, which is an important component of its production processes for solar evaporation ponds at the facilities in Coya Sur, Nueva Victoria and Salar de Atacama. This method gives it an advantage over other processes. It is only posible because the Atacama Desert, where SQM's operations are located, has extremely high levels of solar radiation, resulting in high evaporation rates and facilitating the processes employed to concentrate salts in ponds yearround. SQM's operations are also powered by electricity obtained from the National Electric System (SEN) and cleaner fuels such as oil and natural gas. SQM has approximately 4,000 hectares of solar evaporation ponds, which allow it to harness significant amounts of solar energy, accounting for $91.1 \%$ of all energy consumed in our facilities." Accessed via https://www.sqm.com/en/medio-ambiente/\#energy tab, on $7^{\text {th }}$ August 2021. 
As discussed in the main text, we agree that the working principle behind solar evaporation ponds is solar energy. However, what we discuss in our work, is the energy need in all other the different processes other than evaporation ponds (heating, pumping, chemical reactions, etc. see Figure 1 in the main text). Those processes are not fuelled by solar energy in SQM's plant.

Table S2

Thermal-physical properties for different HTF.

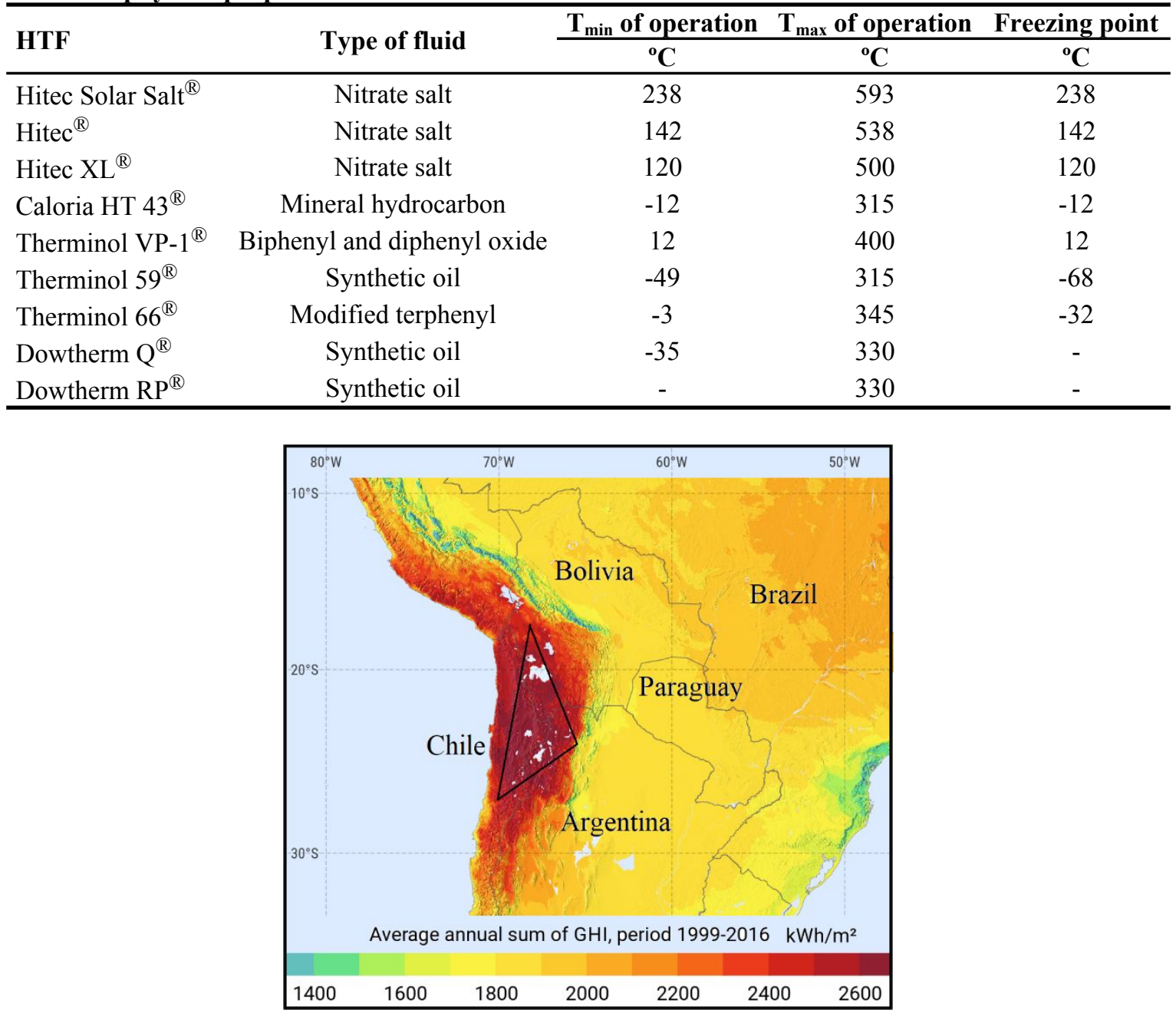

Fig. S1. Annual global horizontal radiation in South America. Source: SOLARGIS, https://solargis.com. 


\section{List of Abbreviations used throughout the text}

$\mathrm{E}_{\mathrm{CO} 2} \quad \mathrm{CO}_{2}$ emissions reduction, (measured in tons of $\mathrm{CO}_{2}$ )

$\mathrm{F}_{\mathrm{e}} \quad$ Emission factor, $\mathrm{tCO}_{2} / \mathrm{dam}^{3}$

$\mathrm{C}_{\mathrm{r}} \quad$ Volumetric consumption of natural gas, dam ${ }^{3}$

CSP Concentrating solar power

DNI Direct normal irradiance

ER Emission reduction

GHG Greenhouse gases

GWP Global warming potential

HCE Heat collection elements

HTF Heat transfer fluid

LCE Lithium carbonate equivalent

LF Linear Fresnel

NSRDB National Solar Radiation Database

PG Pastos Grandes salt lake

PO Pozuelos salt lake

PT Parabolic through

SCA Solar collector assembly

TES Thermal energy storage

\section{References}

Reference numbers here are different from those of the main text.

1. Journal of Cleaner Production, 2012. 23(1): 104-112.

2. Science of the Total Environment, 2018. 639: 1188-1204. 